\title{
Perspectivas de Crescimento da ECONOMIA
}

Luiz, Carlos Bresser Pereira*

A economia brasileira passou por um enorme ajustamento positivo entre 1999 e 2004, que poderia indicar o caminho da retomada do desenvolvimento. Entretanto, não há razão para otimismo por duas razões: porque um problema macroeconômico fundamental e agudo não teve sua solução encaminhada - a taxa de juros Selic - e porque as autoridades monetárias não se revelam suficientemente determinadas a evitar que a taxa de câmbio volte a se valorizar.

O crescimento econômico depende, em primeiro lugar, de estabilidade macroeconômica - estabilidade que não é alcançada no Brasil desde a crise de 1979. Há 25 anos, portanto, o país experimenta alta inflação, e/ ou déficit público, e/ou déficit em conta corrente, e/ou taxas de juros elevadas - os quatro sinais que, isolada ou conjuntamente, indicam a existência de desequilíbrio macroeconômico. Principalmente por essa razão a economia permanece semi-estagnada, apresentando uma taxa média de crescimento per capita inferior a $1 \%$ ao ano.

Em segundo lugar, o crescimento depende da taxa de poupança e de investimento. Esta taxa baixou dos $24 \%$ aproximadamente em que se encontrava no final dos anos 70 para 18 a 19\% nos últimos anos, em grande parte porque a poupança pública tornou-se desde então altamente negativa. Em terceiro lugar, depende da eficiência com que os recursos são utilizados, que baixou nos últimos 50 anos, como é possível ver pela queda da reação marginal produto-capital, que estava próxima de 0,5 e hoje caiu para quase a metade.

É por esta última razão que, de um lado, as reformas institucionais e a reforma da gestão pública, e, de outro, a educação e o desenvolvimento tecnológico e científico são tão importantes. Entretanto, a tese insistentemente repetida pelo governo atual, assim como pelo anterior, de que o equilíbrio macroeconômico foi alcançado, e agora "tudo depende das reformas", constitui grave equivoco. Em primeiro lugar, porque a eficiência no uso dos recursos não depende apenas de mudanças institucionais, mas também de políticas industriais, tecnológicas, educacionais e da gestão pública. Em segundo lugar - e mais importante porque, a curto prazo, o que é preciso é usar plenamente os recursos disponíveis - e isto depende do equilíbrio macroeconômico. Além disso, é preciso aumentar a taxa de 
investimento - o que novamente depende desse equilíbrio, e particularmente de um aspecto fundamental dele: a recuperação da poupança pública.

Ora, tudo indica que o governo continua incapaz de alcançar o equilíbrio macroeconômico. É verdade que tem feito um esforço importante na direção do ajuste fiscal, mas esse esforço é em grande parte neutralizado pela elevada taxa de juros Selic que o Banco Central insiste em pagar aos rentistas brasileiros. Esta taxa, além de ter um efeito fiscal desastroso, porque importa em déficit público e em poupança pública negativa, envolve um subsídio aos rentistas, sendo, portanto, a expressão de sua captura por eles. Mas há um segundo subsídio. A Selic inviabilizaria completamente o investimento privado não fossem os subsídios compensatórios que são oferecidos através da TJLP (Taxa de Juros de Longo Prazo) do BNDES, e dos subsídios ao crédito agrícola. Esses enormes (e necessários) subsídios, entretanto, são incapazes de compensar totalmente as taxas de juros elevadas, já que, no caso da TJLP, apenas as grandes empresas têm acesso a ele.

Nisto tudo o que é irônico e patético é o fato de que esses dois enormes subsídios são os resultados da ortodoxia convencional que domina a política econômica brasileira com o apoio do Fundo Monetário Internacional. Essa ortodoxia convencional, que tanto criticou as políticas industriais do passado, não hesita, hoje, em apoiar subsídios provavelmente maiores, implícitos em uma taxa Selic que deveria e poderia ser três a quatro vezes menores do que é.

A taxa Selic administrada pelo Banco Central encontra-se em um equilíbrio perverso. Se países com igual ou pior classificação de risco que o Brasil podem pagar taxas de juros básicas (que não deve ser confundida com a taxa de longo prazo do mercado) 3 a 4 vezes menores do que a Selic por que o Brasil não pode? Por que é necessária a arbitragem entre a taxa Selic e a taxa de longo prazo, quando se sabe que a taxa Selic é uma taxa de curtíssimo prazo, destinada a remunerar quem, nesse prazo, não tem nem precisa ter alternativa de aplicação de seus recursos monetários? Se o problema está na indexação da Selic à própria Selic, por que não se providencia a desindexação?

O Banco Central não tem resposta a essas perguntas. Ao invés de respondê-las, faz com que a Selic varie, dadas as condições de demanda, entre um piso de $9 \%$ e um teto de $15 \%$ reais, quando poderia e deveria variar entre 2 e $4 \%$ reais. E diz que aquelas taxas astronômicas são necessárias "para combater a inflação". Na verdade, para o Banco Central, que, perversamente, tem apenas uma meta - a de inflação - esta é uma posição muito

\footnotetext{
* Ex-Ministro da República. Professor de Teoria econômica da Fundação Getúlio Vargas (FGV).
} 
cômoda. A situação do governo, que tem também como objetivos o emprego e o equilíbrio da conta corrente do país, é objetivamente menos cômoda, mas não é suficientemente incômoda para levá-lo a desenvolver uma estratégia de baixa dessa taxa. Atemorizado com as ameaças de volta de inflação, ou então de crise de financiamento do Tesouro - ameaças sem base, mas alimentadas por interesses poderosos, que estão capturando no total, quase $10 \%$ do PIB brasileiro - o governo deixa o Banco Central livre para realizar uma política que só interessa aos rentistas.

Nos últimos cinco anos, entretanto, o mercado e os dois governos - o segundo governo FHC e o atual governo Lula - promoveram um grande ajuste macroeconômico no Brasil. O mercado, através de duas crises, promoveu o ajuste mais importante - o da taxa de câmbio, enquanto o governo, a partir de 1999, passou a se empenhar no ajuste fiscal. Foi principalmente o ajuste da taxa de câmbio pelo mercado e pela crise que transformou um grande déficit em conta corrente em superávit. Com isso, a desastrosa política de crescimento com poupança externa (ou seja, com déficit em conta corrente) que apenas valorizava o real e aumentava artificialmente os salários e o consumo, foi abandonada, enquanto aumentava a poupança interna. Isto foi logrado através da queda da renda real dos trabalhadores e da classe média assalariada, que a depreciação cambial causou, e através do ajuste fiscal promovido pelos dois governos, começado em 1999.

Este grande ajuste externo e de poupança, entretanto, está sendo ameaçado agora com a valorização do real em relação ao dólar. É certo que a apreciação da moeda nacional em relação a uma cesta de moedas é menor, mas o fato é que, mesmo considerando essa cesta, a taxa de câmbio real brasileira está se tornando perigosamente valorizada. Os exportadores, principalmente aqueles que nos últimos anos investiram contando com uma taxa de câmbio favorável, já estão sendo vítimas de decepção e sendo obrigados a reverem seus planos de investimentos.

O governo toma medidas tímidas para limitar a apreciação do real, mas o piso de $\mathrm{R} \$$ 3,00 por dólar, que durante algum tempo foi praticado, acabou sendo abandonado. Fala-se tanto em credibilidade por parte da política do governo, e não há dúvida que credibilidade é um bem inestimável, mas que credibilidade pode ter um governo que não logra manter razoavelmente estável e competitiva a taxa de câmbio do país? Mesmo quando o governo intervém, procurando segurar a cotação do dólar, insiste que não está intervindo, preocupado em agradar a ortodoxia oficial dominante lá fora. Uma ortodoxia que tanto critica o populismo, mas que apóia o populismo cambial sem pejo. Uma ortodoxia que tanto critica 
subsídios que distorcem o mercado, mas apóia uma captura sem precedentes do Tesouro Nacional.

O governo está exultante com o crescimento de 5,2\% do ano passado. Mas não está considerando que esse crescimento decorre mais do uso de capacidade ociosa do que de aumento da capacidade produtiva. Que decorre mais do desaparecimento da crise de confiança que rodeou as últimas eleições presidenciais, do que de ações efetivas do próprio governo. É claro que é importante que o governo não se tenha se entregue ao populismo fiscal. Mas isto é o mínimo que se espera de um governo.

Além disso, espera-se dele, no curto prazo, no plano da política macroeconômica, que acabe com essa sangria violenta nos cofres públicos representada pela Selic e pelos subsídios compensatórios. E que mantenha a taxa de câmbio em um nível competitivo. Sem essas duas outras condições, o país continuará a crescer lentamente, e, o que é pior, voltará a aumentar sua fragilidade externa, que ainda é grande.

Essa fragilidade diminuiu graças ao câmbio mais competitivo produzido pelas crises de 1998 e 2002, mas é exatamente esse câmbio que está agora sendo ameaçado. E diminuiu também graças à situação favorável da economia internacional, mas o quadro internacional está em franca deterioração, dada a irresponsabilidade fiscal dos Estados Unidos e a queda livre do dólar, e já obriga a OCDE a rever suas previsões para este ano. Por outro lado, do próprio Estados Unidos, que não está cuidando bem de sua casa, e do Fundo Monetário Internacional, continuam a vir conselhos e estímulos para que se mantenha uma política de câmbio irresponsável, que facilmente nos levará a novas crises, e, conjuntamente com a política perniciosa de juros, promoverá o prolongamento indefinido da semi-estagnação em que nos encontramos desde que deixamos de pensar como uma nação nossa política macroeconômica. 